\title{
Sonic stimulation, and low power microwave radiation can modulate bacterial virulence towards Caenorhabditis elegans
}

\author{
Priya Patel ${ }^{1}$, Hiteshi Patel ${ }^{1}$, Dhara Vekariya ${ }^{1}$, Chinmayi Joshi ${ }^{1}$, Pooja Patel ${ }^{1}$, Steven Muskal ${ }^{2}$, \\ Vijay Kothari ${ }^{1 *}$ \\ ${ }^{1}$ Institute of Science, Nirma University, India \\ ${ }^{2}$ Eidogen-Sertanty Inc., USA \\ *Correspondence: vijay.kothari@nirmauni.ac.in
}

\begin{abstract}
Caenorhabditis elegans worms infected with different pathogenic bacteria were subjected to sonic treatment to investigate whether such sound treatment can exert any therapeutic effect on the infected worms. Sonic therapy corresponding to $400 \mathrm{~Hz}$, and the divine sound 'om' were found to confer protective effect on this nematode worm in face of bacterial infection, particularly that caused by Serratia marcescens or Staphylococcus aureus. The observed effect seemed to occur due to influence of sound on bacteria, and not on the worm. In addition to this, effect of microwave exposure on bacterial virulence was also investigated, wherein microwave exposure was found to reduce virulence of $S$. aureus towards $C$. elegans.
\end{abstract}

Key words: Sonic stimulation; 'Om'; Microwave; Athermal effect; Virulence; Antimicrobial resistance

\section{Introduction}

Infectious microorganisms have plagued mankind since ancient times, and caused numerous deaths throughout the history of humans on earth. Older civilizations with limited understanding of these invisible enemies tried to combat the burden of infections through use of a variety of herbal and herbomineral preparations. Later twentieth century saw the dawn of the antibiotic era. Discovery of antibiotics greatly helped the human race in their fight against the pathogenic microorganisms. However, owing to the development of antimicrobial resistance (AMR), and its promiscuous transfer among various microbial species, it has now become clear that antibiotics alone cannot hold the infectious microbes back, and in addition to the development of new antimicrobials, we need to look for novel non-antibiotic ways to combat microbial virulence, which may not replace the antibiotic use, but may emerge as useful alternative measures. Among such alternative/complementary ways to compromise bacterial virulence, one approach includes the use of non-invasive therapeutics such as electromagnetic radiation (EMR) (Elsheakh, 2017), acoustic waves (Bandara et al., 2014), plasma torch (Thiyagarajan, 2011), etc.

Different parts of the EMR spectrum such as X-rays and UV are known to have deleterious effects on almost all forms of life. Among them, biological effects of microwaves (MW) have received relatively lesser attention from the research community. Particularly the athermal (non-thermal) effect of MW has remained a matter of debate and controversy in the scientific as well as public domain (Singh and Kapoor, 2014). While thermal effects of MW are 
well-established, literature contains papers arguing in favour of the athermal effects, as well as, those indicating otherwise (Leszczynski et al ., 2002; Regel and Achermann, 2011).

Among the most common abiotic factors interacting with life forms, one is sound, which can be classified into infrasound $(<20 \mathrm{~Hz})$, audible sound $(20-20,000 \mathrm{~Hz})$, and ultrasound $(>20$ $\mathrm{KHz}$ ) (Kadam et al., 2016) While ultrasonic frequencies are known to have deleterious effect on microbial cells leading to their lysis, not much research has been done on microbial response to sonic stimulation. Though few reports (Ying et al., 2009; Shaobin et al., 2010; Aggio et al., 2012; Gu et al., 2013; Kim, 2016; Liu et al., 2016; Murphy et al., 2016) have accumulated in literature describing the effect of external sound field on microbial cells, the precise mechanism by which acoustic vibrations affect microbial forms of life, yet remains to be elucidated.

Previously we have reported results of our in vitro experiments describing (a) effect of low power MW on microbial growth/metabolism (Kushwah et al., 2013), protein synthesis (Mishra et al., 2013), enzyme activity (Dholiya et al., 2012), exopolysaccharide production (Kushwah et al., 2013), toxin production (Ramanuj et al., 2015), quorum-sensing (QS) regulated pigment production (Chaudhari et al., 2014), etc.; and (b) effect of sonic stimulation on microbial growth (Sarvaiya and Kothari, 2015; Shah et al., 2016), antibiotic susceptibility (Sarvaiya and Kothari, 2017), and QS-regulated pigment production (Kothari et al., 2017; Kothari et al., 2018). Mutagenic effect of MW has also been previously described by us (Gosai et al., 2013; Kothari et al., 2014). Since QS (process of intercellular communication among bacteria) regulates expression of multiple genes in bacteria, including those associated with virulence, and some QS-regulated pigments (e.g. pyocyanin) are believed to be involved in killing of the eukaryotic hosts by bacterial pathogens, and our previous research indicated the potential of low power MW and sound waves to modulate bacterial QS in vitro; we undertook this study to investigate whether sonic/ MW treatment can modulate virulence of pathogenic bacteria, employing the nematode worm Caenorhabditis elegans as the model host. Pathogenic strains used in this study were Chromobacterium violaceum, Pseudomonas aeruginosa, Serratia marcescens, and Staphylococcus aureus. C. violaceum is considered as an emerging pathogen (Kothari et al., 2017), P. aeruginosa and S. aureus are among the most infamous notorious human-pathogenic bacteria, whose antibiotic-resistant varieties have been listed among the pathogens of high/critical importance by WHO (World Health Organization), and so is the case with the family Enterobacteriaceae (http://www.who.int/en/news-room/detail/27-02-2017-whopublishes-list-of-bacteria-for-which-new-antibiotics-are-urgently-needed) to which $S$. marcescens belongs.

Additionally, we also investigated effect of sonic stimulation on growth of Prevotella melaninogenica and Biofidobacterium bifidum. The former bacterium belongs to the family Prevotellaceae, whose lower abundance has been observed in patients suffering from neurological problems like autism (Qiao et al., 2018), and Parkinson's disorder (PD) (Scheperjans et al., 2015), along with increased Bifidobacteria and Enterobacteriaceae abundance (Petrov et al., 2017). Hence perhaps approaches for modulating abundance of Prevotellaceae, Enterobacteriaceae, and other bacteria like Bifidobacteria and Lactobacillus, whose correlation with neurological disease/ well-being has been indicated in literature, may 
prove of some significance in management of conditions like PD. Among two such bacteria selected for this study, B. bifidum is a human gut inhabitant of gram-positive type, widely used as a probiotic strain with different perceived health benefits (Picard et al., 2005; Ku et al., 2016). Bifidogenic effect of plant products (e.g. prebiotics) or physical agents (e.g. EMR, sound waves) can also be of relevance, as higher abundance of these bacteria has been associated with 'positive mood' (Sarkar et al., 2016). P. melaninogenica (synonymous with Bacteroides melaninogenicus) is an anaerobic gram-negative bacterium, part of common flora present in mouth (Könönen, 1993).

\section{Materials and Methods}

\section{Test organisms}

Details of all the bacteria used in this study are given in Table-1. C. elegans was maintained on Nematode Growing Media (NGM; $3 \mathrm{~g} / \mathrm{L} \mathrm{NaCl}, 2.5 \mathrm{~g} / \mathrm{L}$ Peptone, $1 \mathrm{M} \mathrm{CaCl}_{2}, 1 \mathrm{M} \mathrm{MgSo} 4,5 \mathrm{mg} / \mathrm{mL}$ cholesterol, 1M phosphate buffer of $\mathrm{pH} 6,17 \mathrm{~g} / \mathrm{L}$ agar agar) with $E$. coli OP50 (procured from LabTIE B.V., JR Rosmalen, the Netherlands) as feed. Worm population to be used for the in vivo assay was kept on NGM plates not seeded with E. coli OP50 for three days, before being challenged with test pathogen.

\section{Preparation of sound files}

Two different sound types were used in this study. First type was containing the divine Sanskrit sound ' $O m$ ', for which there is no translation. It is considered to be cosmic sound in Hindu culture (Gurjar and Ladhake, 2016). This sound file was sourced from (https://www.youtube.com/watch?v=yoYrLM5rGX8) which was then converted from mp4 to mp3 format using WavePad Sound Editor Masters Edition v 7.13. Total length of an individual 'om' sound in this file was 13.27 seconds. For the purpose of our experiment, we edited this file using WavePad Sound Editor Masters Edition v 7.13, so that a gap of 1 second occurs between two consecutive 'om' sound.

Another sound file contained the $400 \mathrm{~Hz}$ sound. This sound beep was generated using $\mathrm{NCH}^{\circledR}$ tone generator. The sound file played during the experiment was prepared using WavePad Sound Editor Masters Edition v 7.13 in such a way that there is a time gap of one second between two consecutive beep sounds. Sound pertaining particularly to $400 \mathrm{~Hz}$ was selected, since in our previous experiments we found this frequency at $86 \mathrm{~dB}$ to be capable of modulating QS-regulated production of the pigment prodigiosin in S. marcescens (Kothari et al., 2016).

\section{Sonic stimulation}

Inoculum of the test bacterium was prepared from its activated culture, in sterile normal saline. Optical density of this inoculum was adjusted to 0.08-0.10 at $625 \mathrm{~nm}$ (Agilent Technologies Cary 60 UV-vis spectrophotometer). This standardized inoculum $(10 \% \mathrm{v} / \mathrm{v})$ was used to inoculate suitable growth media $(2 \mathrm{~mL})$ for respective bacteria, followed by incubation under static condition at temp and for time length indicated in Table-1.

Following incubation density of the bacterial suspension was adjusted to $\mathrm{OD}_{764}=1.50$. One hundred $\mu \mathrm{L}$ of this bacterial suspension was mixed with $900 \mu \mathrm{L}$ of M9 buffer $\left(3 \mathrm{~g} / \mathrm{L} \mathrm{KH}_{2} \mathrm{Po}_{4}, 6\right.$ 
$\mathrm{g} / \mathrm{L} \mathrm{Na} \mathrm{HPo}_{4}, 5 \mathrm{~g} / \mathrm{L} \mathrm{NaCl}, 0.1 \%$ 1M MgSo 4 ) containing 10 worms (L3-L4 stage). This experiment was performed in 24-well (sterile, non-treated) polystyrene plates (HiMedia TPG24), and incubation was carried out at $22 \mathrm{C}$. Two such 24-well plates were prepared, one to be treated as 'control', and another as 'experimental', wherein the former did not receive any sonic treatment, and the latter did. The 'experimental' plate was placed below a speaker (Minix sound bar, Maxtone Electronics Pvt. Ltd., Thane), with a distance of $13 \mathrm{~cm}$ between the speaker and the plate. This whole experimental set-up (Figure 1) was placed in a glass jar (Actira, L: $250 \mathrm{x}$ W: 250 x H: $150 \mathrm{~mm}$ ). Speaker was fitted between two side walls of the glass jar in such a way that its sound-emitting surface faces downside towards the 24-well plate lying on the floor of the jar. 24-well plates in both the glass jars were rotated by $180^{\circ}$ once every day, so that all wells can be expected to receive almost equal sound exposure. Sound delivery from the speaker in experimental jar was provided throughout the period of incubation. Glass chambers were covered with a glass lid, and one layer of loose-fill shock absorber polystyrene, in such a way that the polystyrene layer gets placed below the glass lid. Silicone grease was applied on the periphery of the glass chamber coming in contact with the polystyrene material. This type of packaging was done to minimize any possible leakage of sound from inside of the chamber, and also to avoid any interference from external sound. Similar chamber was used to house the 'control' (i.e. not subjected to sound stimulation) plate. One non-playing speaker was also placed in the glass chamber used for the control plate at a distance of $13 \mathrm{~cm}$ from the plate, where no electricity was supplied and no sound was generated (Kothari et al., 2018). Intensity of sound was measured with a digital sound level meter (KUSAM-MECO® KM 929 MK1; detection range $30-130 \mathrm{~dB}$ ) by putting the sensor in place of the 24 -well plate. The display on screen of this meter was visible through the glass of the experimental jars (which were sealed at the time of sound intensity measurement). Background noise (i.e. the sound produced by incubator) was also measured, whose value in the control and experimental jar was recorded to be $57.4 \pm 0.23$ $\mathrm{dB}$ and $58.8 \pm 1.02 \mathrm{~dB}$, respectively. When sound emission was on in the experimental chamber from speaker placed in it, $\mathrm{dB}$ values in the control chamber did not go beyond this background noise, indicating that sound from the experimental chamber did not reach the control chamber. Intensity of $400 \mathrm{~Hz}$ sound in the experimental chamber was set at $85 \pm 0.5 \mathrm{~dB}$, and that of 'om' at $72-75 \mathrm{~dB}$.

Number of live vs. dead worms was counted everyday till five days by putting the plate (with lid) under light microscope (4X). Straight worms were considered to be dead. Plates were gently tapped to confirm lack of movement in the dead-looking worms. On last day of the experiment, when plates could be opened, their death was also confirmed by touching them with a straight wire, wherein no movement was taken as confirmation of death.

\section{Microwave (MW) treatment}

Bacterial suspensions were prepared from an actively growing culture, in sterile normal saline, and its turbidity was adjusted to $0.08-1.00$ at $625 \mathrm{~nm}$. Test cultures $(5 \mathrm{~mL})$ in sterile screw capped glass vials (15 mL; Merck) were exposed to $\mathrm{MW}$ radiation (90 W; $2450 \mathrm{MHz}$ ) in a domestic MW apparatus (Electrolux ${ }^{\circledR}$ EM30EC90SS) for 2, 4, or 6 min. Vials inside the MW apparatus were placed in a ice containing beaker $\left(100 \mathrm{~mL}\right.$; Borosil $\left.{ }^{\circledR}\right)$, so as to avoid any thermal heating. Temperature of the microbial suspension after MW treatment did not go beyond $15.6{ }^{\circ} \mathrm{C}$. (Table 2). Temp measurements before and after MW treatment were carried out using infrared thermometer (KUSAM-MECO® IRL380). The whole MW treatment was performed in an air- 
conditioned room. Untreated inoculum was used as control (receiving no MW exposure, but ice treatment equivalent to that of experimental). Before MW treatment all the inoculum vials were put in ice for 5 min to nullify any variations in initial temperature. In case of control vial, put for $5 \mathrm{~min}$ in ice and then for $5 \mathrm{~min}$ at room temp (instead of MW treatment), the temp of inoculum was found to be $18^{\circ} \mathrm{C}$. Test organisms were immediately (in less than $5 \mathrm{~min}$ ) inoculated (at $10 \% \mathrm{v} / \mathrm{v}$ ) into the growth medium following MW treatment, and incubated at each organism's respective temp for $24 \mathrm{~h}$. At the end of incubation, $1 \mathrm{~mL}$ of the resulting culture was used for estimation of cell density and pigment quantification, and remaining was used for assaying virulence of the bacterial culture in vivo in $C$. elegans model, as described in the preceding section.

\section{Statistical analysis}

All experiments were performed in triplicate, and measurements are reported as mean \pm standard deviation (SD) of $\geq 2$ such independent experiments. Statistical significance of the data was evaluated by applying $t$-test using Microsoft Excel $^{\circledR}$. $P$ values $\leq 0.05$ were considered to be statistically significant.

\section{Results and Discussion}

\section{Effect of sonic stimulation on bacterial virulence}

When $C$. elegans infected with $S$. marcescens were subjected to sonic stimulation (400 $\mathrm{Hz})$, it registered $42 \%$ higher survival, as compared to the infected $C$. elegans receiving no sound treatment (Figure 2). Such notable survival benefit was not observed in case of infections caused by remaining two gram-negative pathogens, considering the number of surviving worms on last day of the experiment. However, statistically significant survival benefit was observed in case of $P$. aeruginosa infection till second day (Figure 3), and in case of $C$. violaceum till fourth day (Figure 4). Sonic stimulation could confer $23 \%$ better survival on C. elegans facing the $S$. aureus challenge (Figure 5). These in vivo observations demonstrating effect of sonic stimulation on these bacteria corroborates well with our in vitro observations reported previously (Kothari et al., 2016) wherein we had shown $400 \mathrm{~Hz}$ sound (at $86 \mathrm{~dB}$ ) to be capable of modulating production of the prodigiosin and violacein pigments in their respective producers. Both these pigments have been reported to possess a variety of biological activities (Liu and Nizet, 2009; Lapenda et al., 2015; Hosokawa et al., 2016), and their production being under control of QS, soundinduced altered production of these pigments may be taken as an indication of QS machinery of the target bacteria to get modulated under influence of external acoustic field. It should be noted that QS is being actively pursued as a potential target for novel anti-pathogenic therapeutics (Holm and Vikstrom, 2014). Modulation of pigment production in these bacteria may not be solely due to effect of sound on QS machinery. Violacein has been reported not to be solely regulated by QS in C. violaceum (de Vasconcelos et al., 2003). Altered prodigiosin production might be linked to disturbance of the energy status of $S$. marcescens cells. Haddix et al. (2008) suggested a negative regulatory role for prodigiosin in cell and energy production under aerobic growth conditions, and that prodigiosin reduces ATP production by a process termed energy 
spilling. This process may protect the cell by limiting production of reactive oxygen compounds. Prodigiosin may also possibly act as a mediator of cell death at population stationary phase. Violacein is probably toxic to C. elegans (Choi et al., 2015), and prodigiosin is also known to exert cytotoxicity (Francisco et al., 2007; Dalili et al., 2012).

When $C$. elegans infected with different bacteria were exposed to 'om' sonic stimulation (Figure 6-9), it registered better survival in face of $S$. marcescens and $S$. aureus challenge, whereas marginal survival benefit seemed to be conferred on this worm owing to sonic stimulation in face of $P$. aeruginosa challenge. In case of $C$. violaceum infection, only a minor (albeit statistically significant) benefit of $7 \%$ could be observed on fourth day post-infection.

From results of both types of sounds used to treat $C$. elegans post-bacterial infection, it seems that infection caused by $S$. marcescens and $S$. aureus respond better to the sonic therapy, whereas outcome of $C$. violaceum infection does not seem to get affected much due to sonic stimulation. In any of these experiments, sonic treatment was not found to have any positive or negative effect on overall survival percentage of $C$. elegans, in absence of bacterial challenge, suggesting that all the observed effect is likely be due to influence of sound on the bacterial pathogen. This is to say that the improved survival of the nematode worm experiencing sonotherapy, in face of bacterial challenge, is very much likely to be due to soundresponsiveness of the bacteria. Insensitivity of wild type C. elegans to low-pressure ultrasound has been reported by Ibsen et al. (2015).

This property of different bacteria to respond to sonic frequencies has been reported earlier. First such report (Matsuhashi et al., 1998) described not only the ability of Bacillus carboniphilus to respond to sound, but also the ability of B. subtilis to produce sound waves. Gu et al. (2013) described alteration in growth and physiological characters of $E$. coli upon exposure to external sound field. Later they ( $\mathrm{Gu}$ et al., 2017) studied differential gene expression in E.coli K12 exposed to sound. First report describing effect of sonic stimulation on bacteria at the whole transcriptome level was made public in Jan 2017 by our group (https://www.biorxiv.org/content/early/2017/01/04/098186). Liu et al. (2016) described germination-promoting effect of sonic stimulation $(5 \mathrm{kHz}$ at $90 \mathrm{~dB})$ on Bacillus endospores. Though now it is known that bacteria and other microbes respond to external sound exposure, which is described in terms of alteration in their growth, metabolism, gene expression etc., the precise mechanism governing this phenomenon of sound-responsiveness among bacteria remains to be found out. The acoustic energy absorbed by bacteria may be postulated to modulate their membrane permeability and enzyme activities. Liu et al (2016) indicated the possibility of increased release of chemical mediators of QS in sound-exposed endospores. We have also shown altered production of QS-regulated pigments in sound-exposed bacterial cultures (Kothari et al., 2017; Kothari et al., 2018). QS being an important regulator of virulence (Natrah et al ., 2011), any chemical or physical agents capable of modulating QS can be expected to modulate bacterial virulence too. Sound waves may exert their effect on bacteria by modulation of the chemotaxis ( $\mathrm{Gu}$ et al., 2017) and/or glucose metabolism pathway (Joshi et al., 2018). These effects may be believed to be dependent on factors like size/ shape of the test bacteria, their growth phase (e.g. logarithmic vs. stationary), etc. Aspect ratio of the bacterial cells/ spores may 
play an important role in determining the magnitude of specific absorption rate toward sound waves (Liu et al., 2016).

\section{Effect of sonic stimulation on $P$. melaninogenica and $B$. bifidum}

First we exposed $P$. melaninogenica to 'Om' sound at two different intensities i.e. 70-75 $\mathrm{dB}$ and $80-85 \mathrm{~dB}$. This sound at 70-75 $\mathrm{dB}$ promoted growth of this bacterium by 5.88-62.93\%. However this growth-promoting effect was observed 4 times out of 6 times we did this experiment (Table 3 ). These results can be said to be inconclusive, as outcome of all the six experiments did not match, and among those four experiments, when growth of the sonic stimulated culture was found to be statistically significantly higher, the range of magnitude of effect (expressed in \%) was a wide range. At present, we are not able to understand and explain the reasons behind these inconclusive results. The same 'Om' sound at bit higher intensity of 80-85 dB failed to exert any influence on this bacterium's growth. Based on these results, we selected this sound at 70-75 dB for treating B. bifidum, but no effect was observed.

Since the 'Om' sound was able to promote growth of $P$. melaninogenica 4 out of 6 times, we identified the major frequency components of this sound, by performing a temporal frequency analysis (TFFT) using NCH WavePad $v$ 7.13. This analysis resulted in identification of five major frequency bands in the poly frequency sound 'om' viz. $136.1 \mathrm{~Hz}, 270 \mathrm{~Hz}, 405 \mathrm{~Hz}$, $540 \mathrm{~Hz}$, and $810 \mathrm{~Hz}$. Following this we generated separate sound beeps for each of these frequencies, and a file containing their combination. These all were pulsed sound files, with a time gap of 1 second between two consecutive beeps. Effect of these six sound types was also checked on these two bacteria, and in none of the case, any reproducible effect on their growth could be observed (data not shown).

\section{Effect of MW treatment on bacterial virulence}

We also investigated effect of low power MW radiation on two of the most notorious humanpathogenic bacteria i.e. P. aeruginosa, and S. aureus. When MW-treated inoculum of these bacteria was inoculated into their respective growth media, at the end of incubation period, growth resulting from the MW-exposed inoculum was not found to be different from that resulting from MW-unexposed inoculum; similarly MW treatment was not found to alter pigment production in these bacteria (Figure 10 and Figure 12). However, virulence of S. aureus culture subjected to 2 min MW exposure was significantly found to be reduced in in vivo assay employing the nematode host, wherein the MW-treated $S$. aureus culture could kill lesser number of worms till fourth day, as compared to the control bacterial culture (Figure 11). Virulence of $P$. aeruginosa was not affected by MW treatment (Figure 13).

In the present study, assessment of bacterial virulence towards $C$. elegans was made using the bacterial cell population originated from MW treated inoculum, and not directly on the MW treated cells. Therefore, the alterations in virulence might be believed to be transferred from the originally MW treated cells to their daughter cells (who did not receive direct MW exposure). As in this study, thermal effect of MW was avoided by putting the inoculum in ice during MW treatment, whatever alterations have been observed (i.e. in case of 2-min MW exposure to $S$. aureus) are most likely a result of MW specific effects (athermal effects), as these changes 
occurred in absence of any noticeable heat generation. Exact mechanism by which MW exert their athermal effects on biological systems is still not clear.

Despite the fact that biological significance of MW-specific athermal effects has not been established beyond doubt, reports indicating their possible existence (Dreyfuss and Chipley 1980; Copty et al., 2006; Carta and Desogus, 2010) has attracted considerable attention. As low intensity MW is believed not to possess sufficient energy for breaking chemical bonds directly, alternative mechanisms of interaction between MW and biological entities are likely to prevail. This situation is somewhat similar to the status of use of 'cold plasma' for germicidal purpose, wherein mode of action is not very clear, that how inactivation of bacteria is achieved by nonthermal plasmas (Morent and De Geyter, 2011; Tipa et al., 2011).

This study attempted to investigate the effect of sonic stimulation, and low-power MW radiation on bacterial virulence. Both these treatments (at least with one test bacterium) were found to be capable of modulating bacterial virulence towards the nematode worm C. elegans, more so with the sonic approach. However not enough research has been reported regarding biological effects of audible range of sound, as well as, low-power MW, particularly at the cellular level. Microorganisms owing to their ease of handling in lab, rapid growth rate, etc. offer a good model for investigation in this area. Though reports describing effect of sound waves or MW on different microbes are there in literature, how they exert their effect remains obscure. Further these being physical agents (like UV), their effects may follow a random pattern, and reproducible results may be difficult to obtain (as happened during our experiments with Prevotella melaninogenica). Further, many of their effects may be reversible, for example a sonic stimulated culture may revert back to the normal behavior, soon after removal of the external acoustic field. Reversible nature of MW-induced mutations has previously been indicated by us (Raval et al., 2014). Though underdeveloped at present, further systematic research in this area may pave the way for development of novel therapeutic applications. Some reports do indicate therapeutic utility of acoustic waves (i.e. sonotherapy), and MW, their use for management of microbial infections has yet not been possible. For example, vibroacoustic therapy is being described as a new sound technology that uses audible sound vibrations to reduce symptoms, invoke relaxation, and alleviate stress. Use of this technology (e.g. in pain management) is based on the fact that external vibration can influence body function (BoydBrewer and McCaffrey, 2004). Music has also been proposed as a therapy for anxiety and pain (Negrete, 2011).However, use of acoustic vibrations for microbiological purposes will be possible only after this area of knowledge gains sufficient attention from the research community, and mechanistic details of how microbes and sound waves interact are understood. Our understanding of whether and how non-auditory eukaryotic cells are affected by sonic stimuli is still fragmentary. Lestard et al. (2013) suggested that music can alter morphofunctional parameters, such as cell size and granularity in cultured cells, and that music can interfere with hormone binding to their targets, indicating that music (audible sounds) could modulate physiological and pathophysiological processes. Our understanding of how nonauditory cells are affected by sonic stimuli may enable the scientific community to devise vibroacoustic therapy for management of microbial infections, and also for disease conditions which are shown to have correlation with alterations in human microbiota. 
Though sonic stimulation in this study was not found to alter growth of $P$. melaninogenica and B. bifidum, it did attenuate virulence of $S$. marcescens towards $C$. elegans. $S$. marcescens is a member of the family Enterobacteriaceae, whose abundance has been reported to be positively associated with the severity of postural instability and gait difficulty in PD patients. C. elegans is a small soil worm or nematode, and it shares a common ancestor with humans that lived in the pre-Cambrian era (500-600 million years ago). This ancestor is referred to as the urbilaterian ancestor, as is believed to be the relative of all bilaterally symmetric, multicellular organisms on the earth, including invertebrates and vertebrates (http://www.people.ku.edu/ erikl/Lundquist_Lab/Why_study_C._elegans.html). It also shares some $40 \%$ similarity with human genome. Our experiments showed sonic treatment to confer notable benefit on $C$. elegans upon challenge with $S$. marcescens. Latter has been known to be involved in human wound infections on skin, and $C$. elegans epidermis has been proposed as a model skin (Chisholm and $\mathrm{Xu}, 2012$ ).

To the best of our awareness, this is the first report, describing sonic/ MW exposure to cause alteration in bacterial virulence towards the nematode $C$. elegans. Further experiment to understand the molecular basis of this phenomenon are warranted. A thorough understanding of the mechanism how EMR or sonic stimulation affects bacterial physiology and virulence is required, for development of any useful therapeutic application of such non-invasive approaches to tackle bacterial infections.

\section{References}

Aggio, R. B. M., Obolonkin, V., and Villas-Bôas, S. G. Sonic vibration affects the metabolism of yeast cells growing in liquid culture: a metabolomic study. Metabolomics, 2012, 8(4), 670-678.

Bandara, H. M. H. N., Harb, A., Kolacny, D., Martins, P., and Smyth, H. D. C. Sound waves effectively assist tobramycin in elimination of Pseudomonas aeruginosa biofilms in vitro. AAPS Pharm.Sci.Tech., 2014, 15(6), 1644-1654.

Boyd-Brewer, C., and McCaffrey, R. Vibroacoustic sound therapy improves pain management and more. Holist Nurs. Pract., 2004, 18(3), 111-118.

Carta, R., and Desogus, F. The effect of low-power microwaves on the growth of bacterial populations in a plug flow reactor. AIChE j., 2010, 56(5), 1270-1278.

Chaudhari, V., Gosai, H., Raval, S. and Kothari, V. Effect of certain natural products and organic solvents on quorum sensing in Chromobacterium violaceum. Asian Pac J Trop Dis., 2014, 7, S204-S211.

Chisholm, A. D. and $\mathrm{Xu}, \mathrm{S}$. The Caenorhabditis elegans epidermis as a model skin. II: differentiation and physiological roles. Wiley Interdisciplinary Reviews: Dev. Biol., 2012, 1(6), 879-902. 
Choi, S. Y., Yoon, K. H., Lee, J. I., and Mitchell, R. J. Violacein: properties and production of a versatile bacterial pigment. BioMed res. Inter., 2015, 1-8.

Copty, A. B., Neve-Oz, Y., Barak, I., Golosovsky, M. and Davidov, D. Evidence for a specific microwave radiation effect on the green fluorescent protein. Biophys. J., 2006, 91(4), 1413-1423.

Dalili, D., Fouladdel, S., Rastkari, N., Samadi, N., Ahmadkhaniha, R., Ardavan, A. and Azizi, E. Prodigiosin, the red pigment of Serratia marcescens, shows cytotoxic effects and apoptosis induction in HT-29 and T47D cancer cell lines. Natural product research, 2012, 26(22), 20782083.

de Vasconcelos, A. T. R., De Almeida, D. F., Hungria, M., Guimarães, C. T., Antônio, R. V., Almeida, F. C. and Araripe, J. The complete genome sequence of Chromobacterium violaceum reveals remarkable and exploitable bacterial adaptability. Proc. Natl. Acad. Sci. U S A, 2003, 100(20) 11660-11665.

Dholiya, K., Patel, D. and Kothari, V. Effect of low power microwave on microbial growth, enzyme activity, and aflatoxin production. Res. Biotechnol., 2012, 3(4), 28-34.

Dreyfuss, M. S. and Chipley, J. R. Comparison of effects of sublethal microwave radiation and conventional heating on the metabolic activity of Staphylococcus aureus. App. Environ. Microbial., 1980, 39(1), 13-16.

El-Fouly, M. Z., Sharaf, A. M., Shahin, A. M., El-Bialy, H. A. and Omara, A. M. A. Biosynthesis of pyocyanin pigment by Pseudomonas aeruginosa. J. Radiat. Res. Appl. Sci. 2015, 8(1), 36-48.

Elsheakh, D. Non-Invasive Electromagnetic Biological Microwave Testing, Microwave Systems and Applications Sotirios Goudos,, InTech.http://dx.doi.org/10.5772/64773

Francisco, R., Pérez-Tomás, R., Gimènez-Bonafé, P., Soto-Cerrato, V., Giménez-Xavier, P. and Ambrosio, S. Mechanisms of prodigiosin cytotoxicity in human neuroblastoma cell lines. Eur J Pharmacol., 2007, 572(2-3), 111-119.

Gosai H., Raval S., Chaudhari V.and Kothari V. Microwave mutagenesis for altered lactic acid production in Lactobacillus plantarum, and Streptococcus mutans. Curr. Trends. Biotechnol. Pharm., 2014, 8 (4) 402-412.

Gu, S. B., Yang, B., Wu, Y., Li, S. C., Liu, W., Duan, X. F. and Li, M. W. Growth and physiological characteristics of E. coli in response to the exposure of sound field. Pak. J. Biol. Sci., 2013, 16(18), 969-975.

$\mathrm{Gu}, \mathrm{S}$., Qiao, S. and $\mathrm{Wu}, \mathrm{Y}$. The influence of metabolic network structures and energy metabolic pattern on E. coli K12 exposed to acoustic field: based on Gene Ontology and KEGG pathway enrichment analysis. PeerJ PrePrints, 2017.

Gurjar, A. A. and Ladhake, S. A. Analysis and Dissection of Sanskrit Divine Sound "OM" Using Digital Signal Processing to Study the Science Behind "OM" Chanting. 2016 7th International Conference on Intelligent Systems, Modelling and Simulation (ISMS). 
Haddix, P. L., Jones, S., Patel, P., Burnham, S., Knights, K., Powell, J. N. and LaForm, A. Kinetic analysis of growth rate, ATP, and pigmentation suggests an energy-spilling function for the pigment prodigiosin of Serratia marcescens. J. Bacteriol., 2008, 190(22), 7453-7463.

Holm, A. and Vikstrom, E. Quorum sensing communication between bacteria and human cells: signals, targets, and functions. Front. Plant. Sci., 2014, 5, 309.

Hosokawa, K., Soliev, A. B., Kajihara, A. and Enomoto, K. Effects of a microbial pigment violacein on the activities of protein kinases. Cogent Biol., 2016, 2(1), 1259863.

Ibsen, S., Tong, A., Schutt, C., Esener, S. and Chalasani, S.H. Sonogenetics is a non-invasive approach to activating neurons in Caenorhabditis elegans. Nat. Commun., 2015, 6(1), 1-12.

Joshi C, Patel P, Singh A, Sukhadiya J, Shah V, Kothari V (2018). Frequency-dependent response of Chromobacterium violaceum to sonic stimulation and altered gene expression associated with enhanced violacein production at $300 \mathrm{~Hz}$. Current Science, 114 (accepted).

Kadam, V. V. and Nayak, R. Basics of Acoustic Science' in R Padhye, R Nayak (ed.) Acoustic Textiles, Springer, Singapore, 2016, 33-42.

Kim, H. W. The effects of low frequency noise on the growth and resistance to antibiotics of soil bacteria and E. coli. APEC Youth Scientist J., 2016, 8(1), 1-10.

Könönen, E. Pigmented Prevotella species in the periodontally healthy oral cavity. FEMS Immunol Medical Microbiol, 1993, 6(2-3), 201-205.

Kothari V., Mishra T. and Kushwah P. Mutagenic effect of microwave radiation on exopolysaccharide production in Xanthomonas campestris. Curr. Trends Biotechnol. Pharm., 2014, 8 (1) 29-37.

Kothari, V., Joshi, C., Patel, P., Mehta, M., Dubey, S., Mishra, B. and Sarvaiya, N. Influence of a mono-frequency sound on bacteria can be a function of the sound-level. Indian J. Sci. Technol., 2018 11(4).

Kothari, V., Patel, P., Joshi, C., Mishra, B., Dubey, S., and Mehta, M. Quorum sensing modulatory effect of sound stimulation on Serratia marcescens and Pseudomonas aeruginosa. Curr. Trends Biotechnol. Pharm, 2016, 11 (2), 121-128

Kothari, V., Sharma, S., Padia, D. Recent research advances on Chromobacterium violaceum. Asian Pac. J. Trop. Dis., 2017, 10(8), 744-752.

Ku, S., Park, M. S., Ji, G. E. and You, H. J. Review on Bifidobacterium bifidum bgn4: functionality and nutraceutical applications as a probiotic microorganism. Inter. J. Mol. Sci., 2016, 17(9), 1544.

Kushwah, P., Mishra, T. and Kothar, V. Effect of Microwave Radiation on Growth, Enzyme Activity (Amylase and Pectinase), and/or Exopolysaccharide Production in Bacillus subtilis, Streptococcus mutans, Xanthomonas campestris and Pectobacterium carotovora, Br. Microbiol. Res. J., 2013,3(4), 645-653. 
Lapenda, J. C., Silva, P. A., Vicalvi, M. C., Sena, K. X. F. R. and Nascimento, S. C. Antimicrobial activity of prodigiosin isolated from Serratia marcescens UFPEDA 398. World J. Microbiol. Biotechnol., 2015, 31(2), 399-406.

Lestard, N. R., Valente, R. C., Lopes, A. G. and Capella M. A. M. Direct effects of music in nonauditory cells in culture. Noise and Health, 2013, 15(66), 307-14.

Leszczynski, D., Joenväärä, S., Reivinen, J., and Kuokka, R. Non-thermal activation of the hsp27/p38MAPK stress pathway by mobile phone radiation in human endothelial cells: molecular mechanism for cancer- and blood-brain barrier-related effects. Differentiation, 2002, 70, 120-129.

Liu, G. Y. and Nizet, V. Color me bad: microbial pigments as virulence factors. Trends Microbiol., 2009, 17(9), 406-413.

Liu, S. L., Wu, W. J. and Yung, P. T. Effect of sonic stimulation on Bacillus endospore germination. FEMS Microbiol. Lett., 2016, 363(1).

Matsuhashi, M., Pankrushina, A. N., Takeuchi, S., Ohshima, H., Miyoi, H., Endoh, K. and Mano, Y. Production of sound waves by bacterial cells and the response of bacterial cells to sound. J. Gen. Appl. Microbiol., 1998, 44(1), 49-55.

Mishra, T., Kushwah, P. and Kothari, V. Effect of low power microwave on bacterial growth, protein synthesis, and intracellular enzyme (glucose-6-phosphatase and $\beta$-galactosidase) activity. Biochem. Mol. Biol., 2013, 1(2), 27-33.

Morent, R., and De Geyter, N. Inactivation of bacteria by non-thermal plasmas. In Biomedical Engineering-Frontiers and Challenges, 2013 InTech.

Murphy, M. F., Edwards, T., Hobbs, G., Shepherd, J. and Bezombes, F. Acoustic vibration can enhance bacterial biofilm formation. J. Biosci. Bioeng., 2016, 122(6), 765-770.

Natrah, F. M. I., Ruwandeepika, H. D., Pawar, S., Karunasagar, I., Sorgeloos, P., Bossier, P. and Defoirdt, T. Regulation of virulence factors by quorum sensing in Vibrio harveyi. Vet. Microbiol., 2011, 154(1-2), 124-129.

Negrete, B. J. Use of Music Therapy in the Emergency Room for Pain and Anxiety Management, 2011, Retrieved from http://purl.flvc.org/fsu/fd/FSU_migr_etd-2693.

Petrov, V. A., Saltykova, I. V., Zhukova, I. A., Alifirova, V. M., Zhukova, N. G., Dorofeeva, Y. B. and Mironova, Y. S. Analysis of Gut Microbiota in Patients with Parkinson's Disease. Bul.l Exp. Biol. Med., 2017, 162(6), 734-737.

Picard, C., Fioramonti, J., Francois, A., Robinson, T., Neant, F. and Matuchansky, C. bifidobacteria as probiotic agents-physiological effects and clinical benefits. Aliment Pharmacol. Ther., 2005, 22(6), 495-512. 
Qiao, Y., Wu, M., Feng, Y., Zhou, Z., Chen, L. and Chen, F. Alterations of oral microbiota distinguish children with autism spectrum disorders from healthy controls. Sci. Rep., 2018, 8(1), 1597.

Ramanuj, K., Bachani, P., and Kothari, V. In vitro antimicrobial activity of certain plant products/seed extracts against multidrug resistant Propionibacterium acnes, Malassezia furfur, and aflatoxin producing Aspergillus flavus. Res. Pharm., 2015, 2(3).

Raval, S., Chaudhari, V., Gosai, H. and Kothari, V. Effect of low power microwave radiation on pigment production in bacteria. Microbiol. Res., 2014, 5(1).

Regel, S. J. and Achermann, P. "Cognitive performance measures in bioelectromagnetic research critical evaluation and recommendations," Environmental Health, 2011 10, article 10.

Sarkar, A., Lehto, S. M., Harty, S., Dinan, T. G., Cryan, J. F., and Burnet, P. W. Psychobiotics and the manipulation of bacteria-gut-brain signals. Trends Neurosci,, 2016, 39(11), 763-781.

Sarvaiya, N. and Kothari, V. Effect of audible sound in form of music on microbial growth and production of certain important metabolites. Microbiol., 2015, 84(2), 227-235.

Sarvaiya, N. and Kothari, V. Audible Sound in Form of Music Can Influence Microbial Growth, Metabolism and Antibiotic Susceptibility. J. Appl. Biotechnol. Bioeng., 2017, 2(6), 00048.

Scheperjans, F., Aho, V., Pereira, P. A., Koskinen, K., Paulin, L., Pekkonen, E. and Kinnunen, E. Gut microbiota are related to Parkinson's disease and clinical phenotype. Mov. Disord., 2015, 30(3), 350-358.

Shah, A., Raval, A. and Kothari, V. Sound stimulation can influence microbial growth and production of certain key metabolites. J. Microbiol. Biotechnol. Food Sci., 2016, 5(4), 330.

Shaobin, G., Wu, Y., Li, K., Li, S., Ma, S., Wang, Q. and Wang, R. A pilot study of the effect of audible sound on the growth of Escherichia coli. Colloids Surf B Biointerfaces., 2010, 78(2), 367-371.

Singh, S. and Kapoor, N. Health Implications of Electromagnetic Fields, Mechanisms of Action, and Research Needs. Adv. Biol., 2014, 1-24.

Song, Y., Liu, C., Lin, F. Y., No, J. H., Hensler, M., Liu, Y., Jeng, W., Low, J., Liu, G. Y., Nizet, V., Wang, Andrew, H.-J. and Oldfield, E. Inhibition of Staphyloxanthin virulence factor biosynthesis in Staphylococcus aureus: In vitro, in vivo, and crystallographic results. J. Med. Chem., 2009, 52(13), 3869-3880.

Thiyagarajan, M. Portable plasma medical device for infection treatment and wound healing. In ASME 2011 6th Frontiers in Biomedical Devices Conference. American Society of Mechanical Engineers, 2011, 30-32

Tipa, R. S., Boekema, B., Middelkoop, E. and Kroesen, G. M. W. (n.d.), "Cold Plasma for Bacterial Inactivation.” Retrieved from http://www.ispcconference.org/ispcproc/ispc20/312.pdf, [Accessed on 10 June 2015.] 
Unni, K., Priji, P., Geoffroy, V., Doble, M. and Benjamin, S. Pseudomonas aeruginosa BUP2A novel strain isolated from malabari goat produces Type 2 pyoverdine. Adv. Biosci. Biotechnol. 2014, 5(11), 874-885.

Ying, J. C. L., Dayou, J. and Phin, C. K. Experimental investigation on the effects of audible sound to the growth of Escherichia coli. Mod. Appl. Sci., 2009, 3(3), 124. 
Table 1. Test organisms

\begin{tabular}{|c|c|c|c|c|c|}
\hline $\begin{array}{l}\text { Sr. } \\
\text { no. }\end{array}$ & Organism & Strain No. & Growth media & $\begin{array}{l}\text { Incubation } \\
\text { time }(h)\end{array}$ & $\begin{array}{l}\text { Incubation } \\
\text { conditions }\end{array}$ \\
\hline 1 & $\begin{array}{c}\text { Chromobacterium } \\
\text { violaceum }\end{array}$ & MTCC 2656 & $\begin{array}{l}\text { Nutrient Broth } \\
\text { (HiMedia) }\end{array}$ & \multirow{2}{*}{24} & \multirow{3}{*}{$37^{\circ} \mathrm{C}$} \\
\hline 2 & $\begin{array}{c}\text { Pseudomonas } \\
\text { aeruginosa }\end{array}$ & $\begin{array}{c}\text { Our internal culture } \\
\text { collection }\end{array}$ & $\begin{array}{l}\text { Pseudomonas broth } \\
\text { (HiMedia) }\end{array}$ & & \\
\hline 3 & Staphylococcus aureus & MTCC 737 & $\begin{array}{l}\text { Tryptone yeast } \\
\text { extract broth } \\
\text { (HiMedia) }\end{array}$ & \multirow{2}{*}{48} & \\
\hline 4 & Serratia marcescens & MTCC 97 & $\begin{array}{l}\text { Nutrient Broth } \\
\text { (HiMedia) }\end{array}$ & & $28^{\circ} \mathrm{C}$ \\
\hline 5 & $\begin{array}{c}\text { Prevotella } \\
\text { melaninogenica }\end{array}$ & ATCC 25845 & $\begin{array}{l}\text { Composition per L: } \\
\text { Tryptone Soy Broth } \\
30 \mathrm{~g}, \mathrm{~K}_{2} \mathrm{HPO}_{4} 5 \mathrm{~g}, \\
\text { Yeast extract } 5 \mathrm{~g}, \\
\text { Resazurin } 0.01 \mathrm{~g} \\
\text { DHNA 0.1 g, After } \\
\text { autoclave: Vitamin } \\
\mathrm{K}_{1} 0.2 \mathrm{ml}, \mathrm{Hemin} 5 \\
\mathrm{~g}, \text { Cystein } \mathrm{HCl} 0.25 \\
\text { g, pH 6.8-7 }\end{array}$ & 24 & \multirow[t]{2}{*}{$\begin{array}{c}37^{\circ} \mathrm{C} \\
\text { (Anaerobic condition } \\
\text { was maintained using } \\
\text { Anaerogas pack; } \\
\text { HiMedia) }\end{array}$} \\
\hline 6 & $\begin{array}{l}\text { Bifidobacterium } \\
\text { Bifidum }\end{array}$ & NCDC 255 & $\begin{array}{l}\text { MRS media } \\
\text { (HiMedia) }\end{array}$ & 24 & \\
\hline
\end{tabular}

MTCC: Microbial Type Culture Collection, ATCC: American Type Culture Collection, NCDC: National Collection of Dairy Culture. C. violaceum and $S$. marcescens strains used in this study were resistant to cefadroxil (30 $\mu \mathrm{g})$, ampicillin $(10 \mu \mathrm{g})$, cloxacillin $(1 \mu \mathrm{g})$, and penicillin $(10 \mu \mathrm{g})$. S. marcescens showed resistance against vancomycin $(30 \mu \mathrm{g})$, too. . aeruginosa was resistant to amoxicillin $(30 \mu \mathrm{g})$, cefadroxil $(30 \mu \mathrm{g})$, ampicillin $(10 \mu \mathrm{g})$, cloxacillin $(1$ $\mu \mathrm{g})$, penicillin $(10 \mu \mathrm{g})$, chloramphenicol $(30 \mu \mathrm{g})$, cefixime $(5 \mu \mathrm{g})$, clindamycin $(2 \mu \mathrm{g})$, and nitrofurantoin $(300 \mu \mathrm{g})$. 


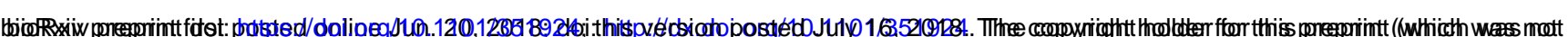

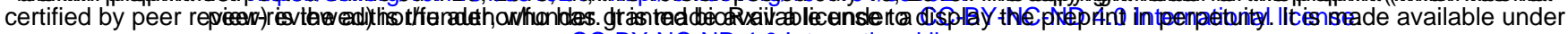
aCC-BY-NC-ND 4.0 International license.

Table 2: Temperature measurements before and after MW treatment of bacterial suspension

\begin{tabular}{|c|c|c|c|c|}
\hline \multirow{2}{*}{$\begin{array}{c}\text { Duration of MW } \\
\text { exposure }\end{array}$} & \multicolumn{2}{|c|}{ P. aeruginosa } & \multicolumn{2}{c|}{ S. aureus } \\
\cline { 2 - 5 } & $\begin{array}{c}\text { Before MW } \\
\text { treatment (ice } \\
\text { treatment for 5 } \\
\text { min) }\end{array}$ & $\begin{array}{c}\text { After MW } \\
\text { treatment }\end{array}$ & $\begin{array}{c}\text { Before MW } \\
\text { treatment (ice } \\
\text { treatment for 5 } \\
\text { min) }\end{array}$ & $\begin{array}{c}\text { After MW } \\
\text { treatment }\end{array}$ \\
\hline $2 \mathrm{~min}$ & 14 & 15.6 & 13.9 & 15.5 \\
\hline $4 \mathrm{~min}$ & 14.6 & 15.4 & 14.4 & 15.3 \\
\hline $6 \mathrm{~min}$ & 15 & 15.2 & 15.1 & 15.2 \\
\hline
\end{tabular}

Immediately after suspending bacterial cells in normal saline, and OD standardization, temp of the bacterial suspensions was found to be $29.5 \pm 0.1^{\circ} \mathrm{C}$.

Table 3. Effect of 'om' on P. melaninogenica and B. bifidum

\begin{tabular}{|c|c|c|c|c|c|c|}
\hline $\begin{array}{l}\text { Sr. } \\
\text { no. }\end{array}$ & Organism & $\begin{array}{l}\text { Sound } \\
\text { intensity } \\
\text { (dB) }\end{array}$ & $\begin{array}{c}\text { Experi- } \\
\text { ment } \\
\text { No. }\end{array}$ & $\begin{array}{c}\text { Control }\left(\text { OD }_{764}\right) \\
(\text { Mean } \pm \text { SD })\end{array}$ & $\begin{array}{l}\text { Experiment }\left(\mathrm{OD}_{764}\right) \\
(\text { Mean } \pm \text { SD })\end{array}$ & $\begin{array}{c}\% \text { change } \\
(\text { Mean } \pm \text { SD })\end{array}$ \\
\hline \multirow{8}{*}{1} & \multirow{8}{*}{$\begin{array}{c}P . \\
\text { melaninogenica }\end{array}$} & \multirow{6}{*}{$70-75$} & 1 & $0.56 \pm 0.005$ & $0.64 \pm 0.01$ & $14.13 * * \pm 3.66$ \\
\hline & & & 2 & $0.76 \pm 0.02$ & $0.83 \pm 0.02$ & $11.37 * \pm 4.92$ \\
\hline & & & 3 & $0.59 \pm 0.007$ & $0.63 \pm 0$ & $5.88^{*} \pm 1.25$ \\
\hline & & & 4 & $0.65 \pm 0.04$ & $0.66 \pm 0.12$ & $1.11 \pm 12.98$ \\
\hline & & & 5 & $0.53 \pm 0.05$ & $0.54 \pm 0.02$ & $3.63 \pm 15.06$ \\
\hline & & & 6 & $0.58 \pm 0.014$ & $0.90 \pm 0.02$ & $62.93 * * \pm 0.31$ \\
\hline & & \multirow{2}{*}{$80-85$} & 1 & $0.65 \pm 0.08$ & $0.65 \pm 0.07$ & $0.63 \pm 20.72$ \\
\hline & & & 2 & $0.64 \pm 0.07$ & $0.56 \pm 0.10$ & $-10.88 \pm 28.24$ \\
\hline \multirow{3}{*}{2} & \multirow{3}{*}{ B. bifidum } & \multirow{3}{*}{$71-75$} & 1 & $0.72 \pm 0.007$ & $0.72 \pm 0.01$ & $-0.67 \pm 2.91$ \\
\hline & & & 2 & $0.73 \pm 0.03$ & $0.85 \pm 0.01$ & $15.82 * \pm 7.49$ \\
\hline & & & 3 & $0.3 \pm 0.04$ & $0.40 \pm 0.02$ & $35.35 \pm 28.56$ \\
\hline
\end{tabular}

$* \mathrm{p}<0.05, * * \mathrm{p}<0.01 ;$; 'sign indicates a decrease over control 


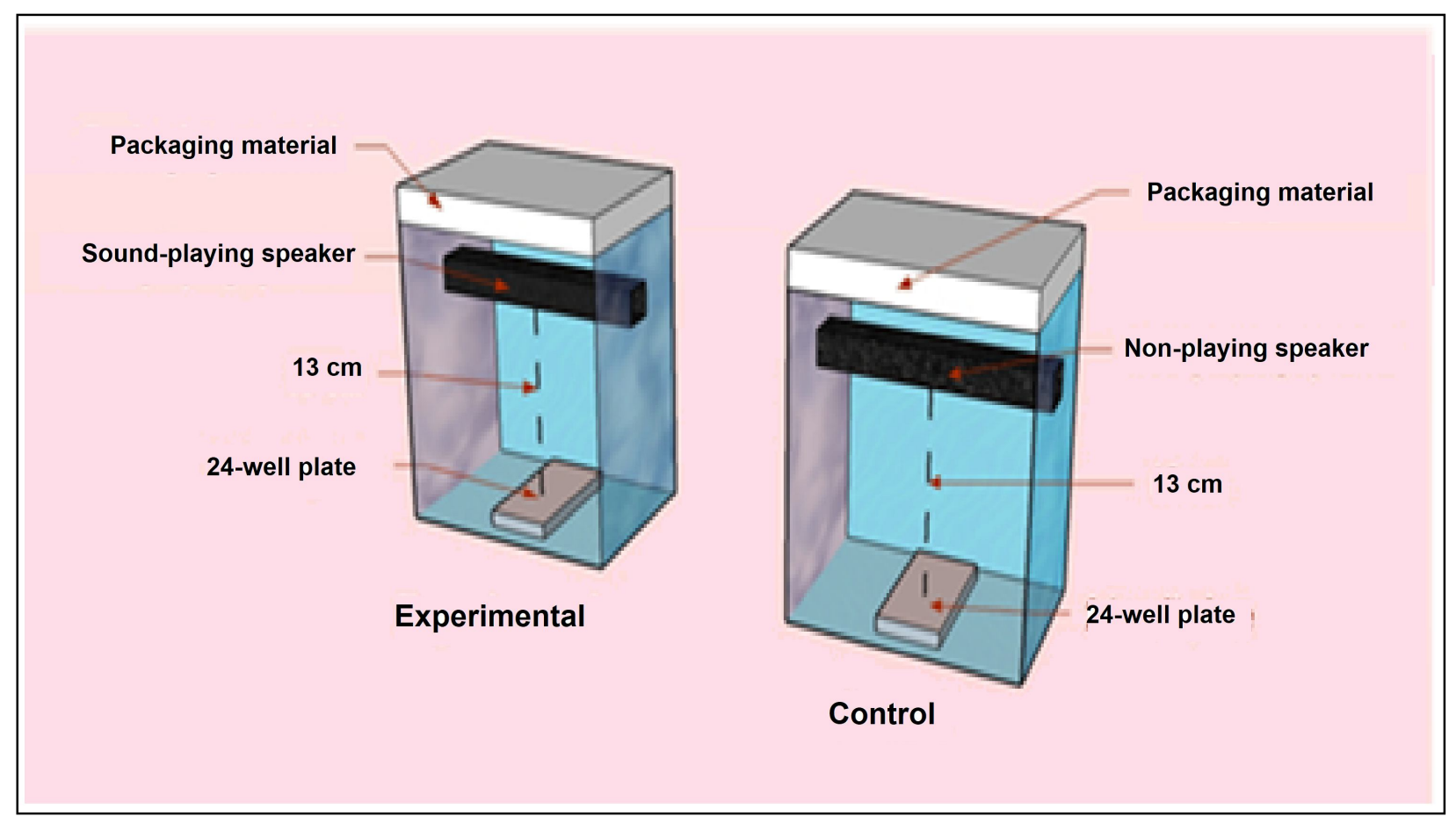

Figure 1. Experimental set up for investigating effect of sonic stimulation on infected C. elegans

Chambers were put in incubator taking care that neither they touch the incubator walls, nor to each-other, so that no vibrations are transferred. 


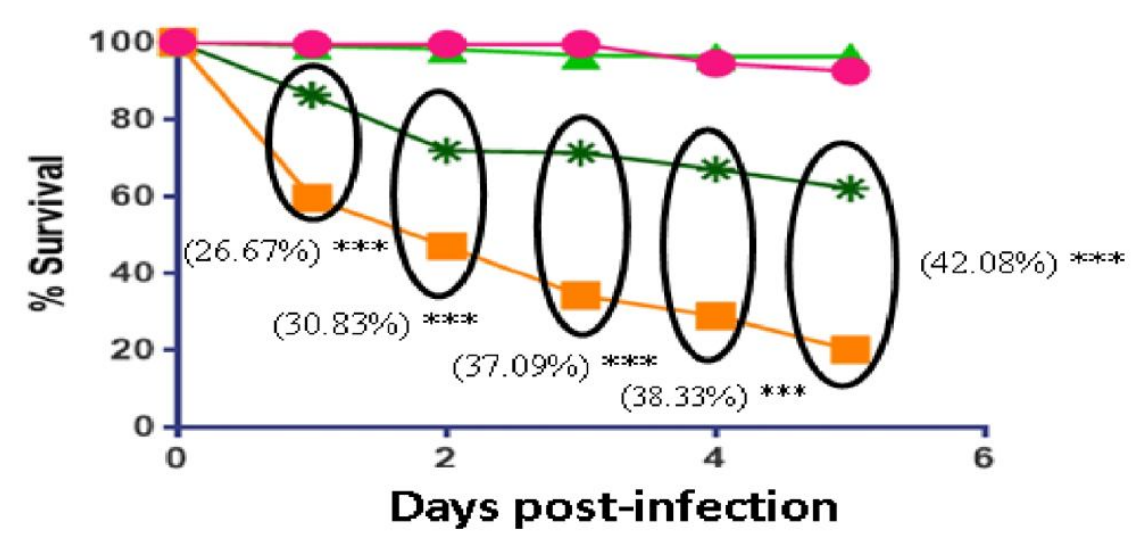

- Unchallenged C. elegans

C. elegans challenged with S. marcescens

- Unchallenged $C$. elegans with sound treatmet

$*$ C. elegans receiving post-infection sound treatment

Figure 2. Post-infection sound treatment $(400 \mathrm{~Hz} ; 85.5 \mathrm{~dB})$ on $C$. elegans challenged with $S$. marcescens

Values reported are means of 6 independent experiments; ***p<0.001 


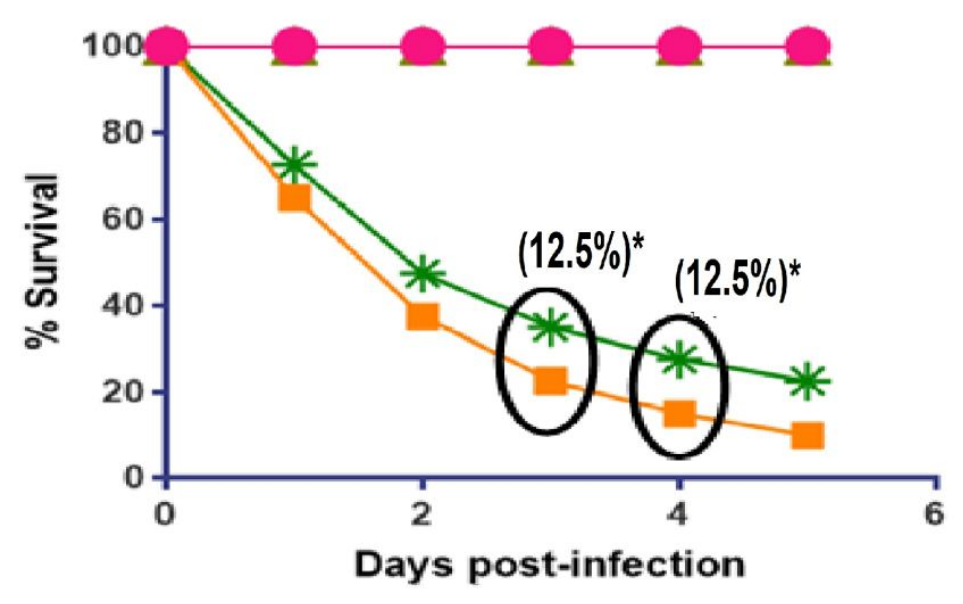

Unchallenged C. elegans

C. elegans challenged with $C$. violaceum

t- Unchallenged $C$. elegans with sound treatment

* C. elegans receiving post-infection sound treatment

Figure 3. Post-infection sound treatment $(400 \mathrm{~Hz} ; 85.5 \mathrm{~dB})$ on $C$. elegans challenged with $P$. aeruginosa

Values reported are means of 2 independent experiments; $*$ * $p<0.01, * * * p<0.001$ 


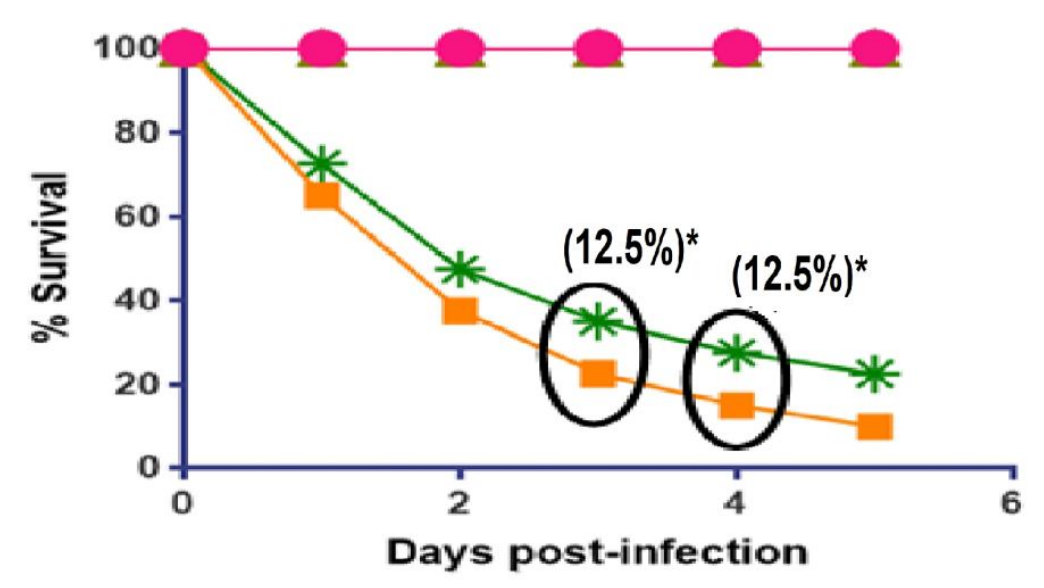

Unchallenged C. elegans

- C. elegans challenged with C. violaceum

A- Unchallenged $C$. elegans with sound treatment

* C. elegans receiving post-infection sound treatment

Figure 4. Post-infection sound treatment $(400 \mathrm{~Hz}$; $85.5 \mathrm{~dB})$ on $C$. elegans challenged with $C$. violaceum

Values reported are means of 2 independent experiments; ${ }^{*} \mathrm{p}<0.05$ 


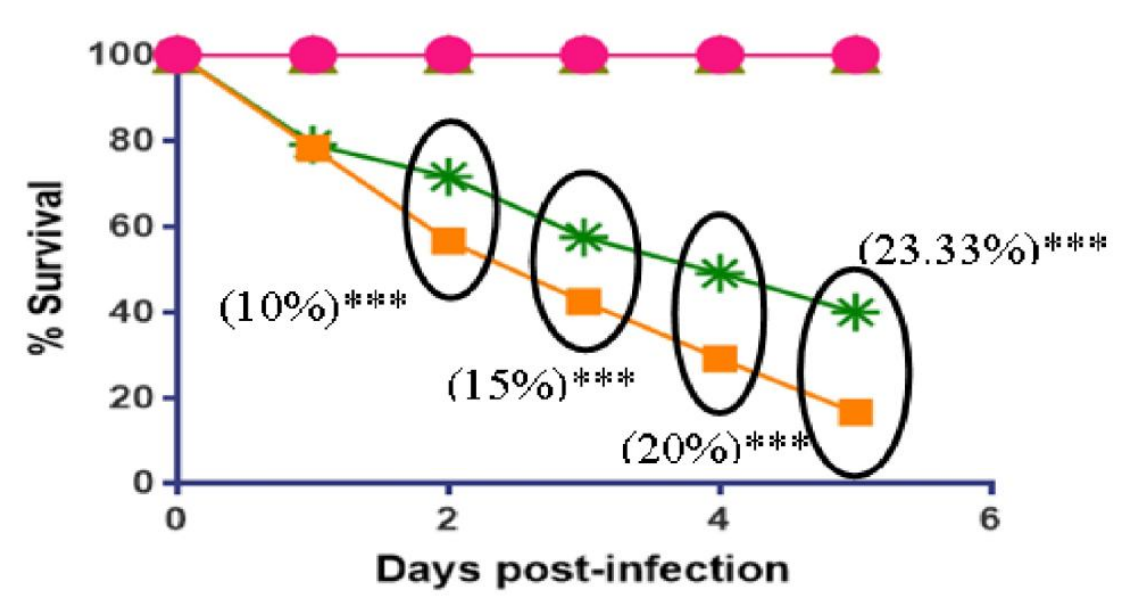

Unchallenged C.elegans

C. elegans challenged with S. aureus

- Unchallenged $C$. elegans with sound treatment * C. elegans receiving post-infection sound treatment

Figure 5. Post-infection sound treatment $(400 \mathrm{~Hz} ; 85.5 \mathrm{~dB})$ on C. elegans challenged with $S$. aureus

Values reported are means of 3 independent experiments; $* * * \mathrm{p}<0.001$ 


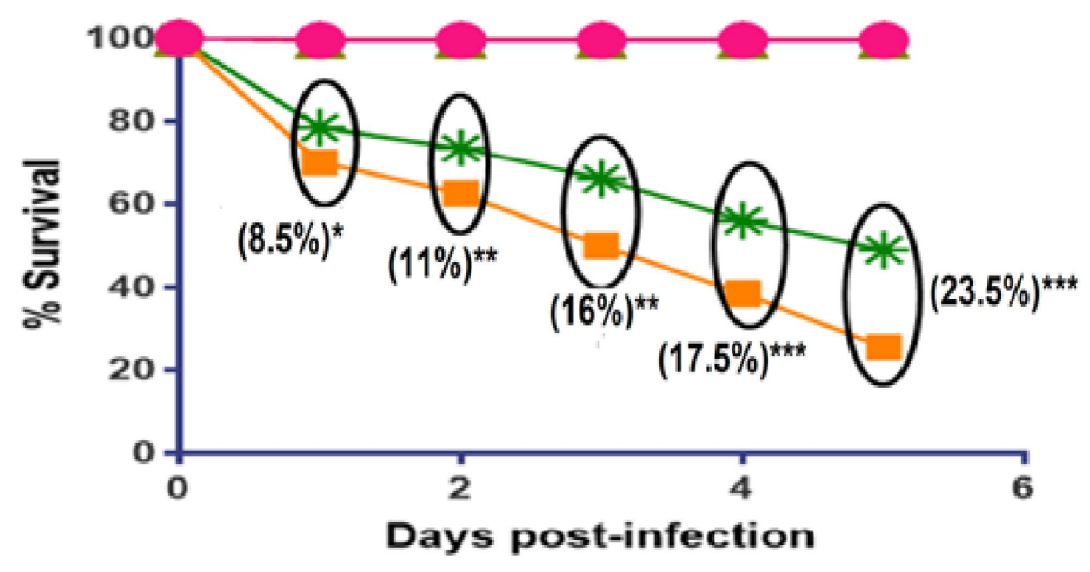

- Unchallenged C. elegans

- C. elegans challenged with $S$. marcescens

- Unchallenged $C$. elegans with sound treatment

$*$ * C. elegans receiving post-infection sound treatment

Figure 6. Post-infection sound treatment $(\mathrm{Om} ; 72-75 \mathrm{~dB})$ on C. elegans challenged with $S$. marcescens

Values reported are means of 5 independent experiments; ${ }^{*} \mathrm{p}<0.05, * * \mathrm{p}<0.01, * * * \mathrm{p}<0.001$ 


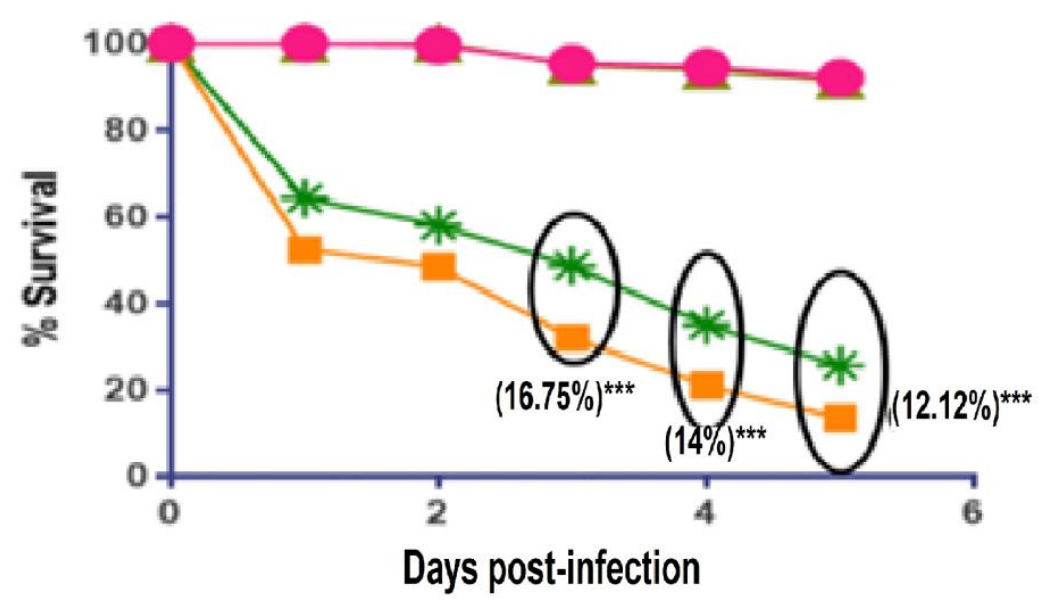

Unchallenged C. elegans

- C. elegans challenged with $P$. aeruginosa

- Unchallenged C. elegans with sound treatment

* C. elegans receiving post-infection sound treatment

Figure 7. Post-infection sound treatment (Om; 72-75 dB) on C. elegans challenged with $P$. aeruginosa

Values reported are means of 6 independent experiments; $* * * \mathrm{p}<0.001$ 


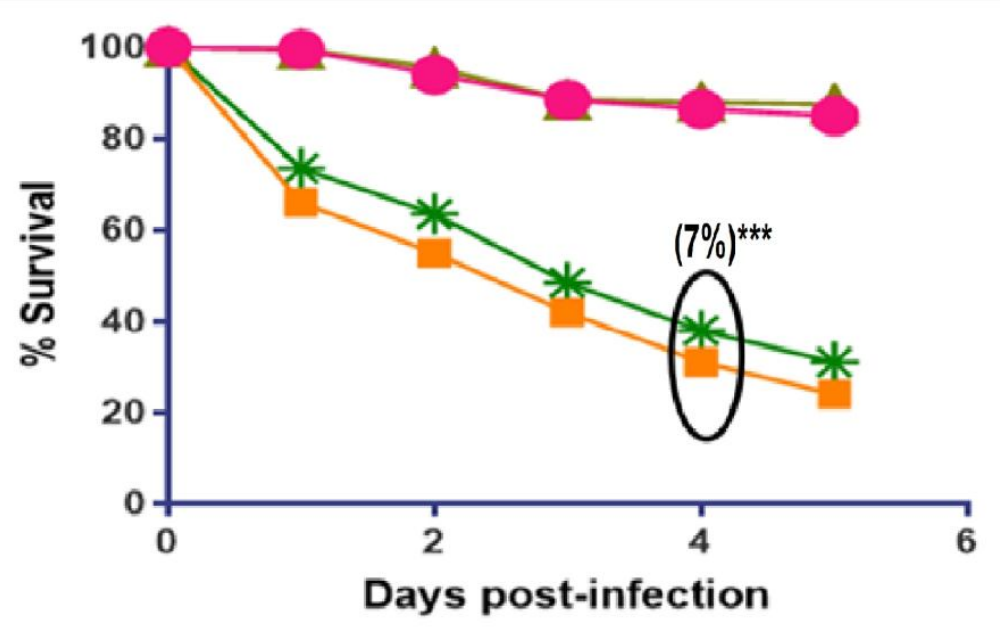

\section{Unchallenged C. elegans}

\section{C. elegans challenged with C. violaceum}

- Unchallenged $C$. elegans with sound treatment * C. elegans receiving post-infection sound treatment

Figure 8. Post-infection sound treatment $(\mathrm{Om} ; 72-75 \mathrm{~dB})$ on C. elegans challenged with $C$. violaceum

Values reported are means of 5 independent experiments; $* * * \mathrm{p}<0.001$ 


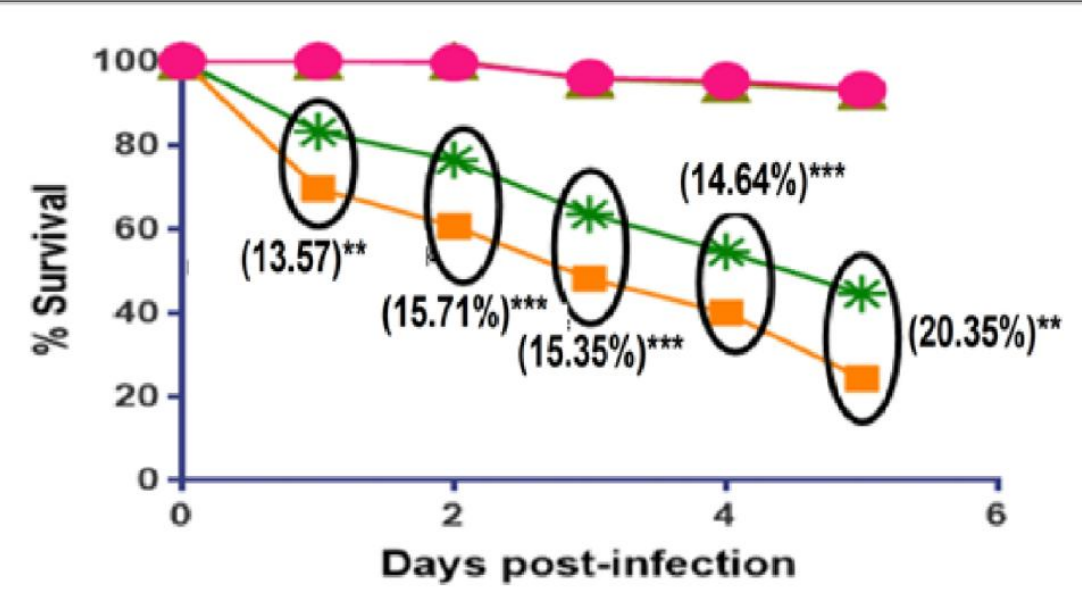

\section{Unchallenged C. elegans}

C. elegans challenged with $S$. aureus

Unchallenged $C$. elegans with sound treatment

* C. elegans receiving post-infection sound treatment

Figure 9. Post-infection sound treatment (Om; 72-75 dB) on C. elegans challenged with $S$. aureus

Values reported are means of 7 independent experiments; **p $<0.01, *^{* *} \mathrm{p}<0.001$ 


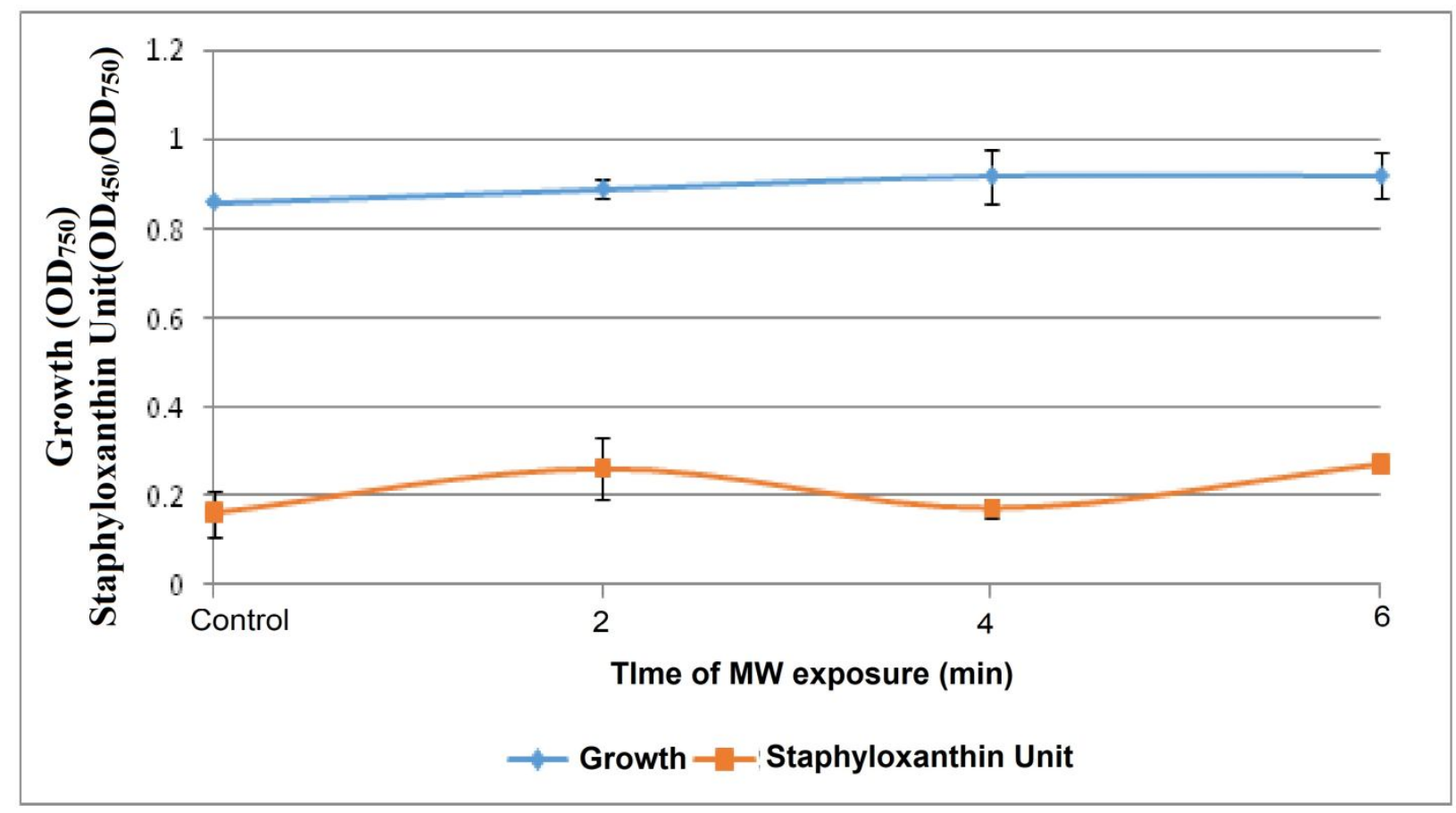

Figure 10. S. aureus growth and pigment production were not affected by MW treatment

Bacterial growth was measured as $\mathrm{OD}_{764}$; OD of staphyloxanthin was measured at $450 \mathrm{~nm}$, and Staphyloxanthin Unit was calculated as the ratio $\mathrm{OD}_{450} / \mathrm{OD}_{750}$ (indication of staphyloxanthin production per unit of growth). Pigment (staphyloxanthin) extraction and quantification was done as described in Song et al. (2009). Bacterial culture not exposed to MW served as control. 


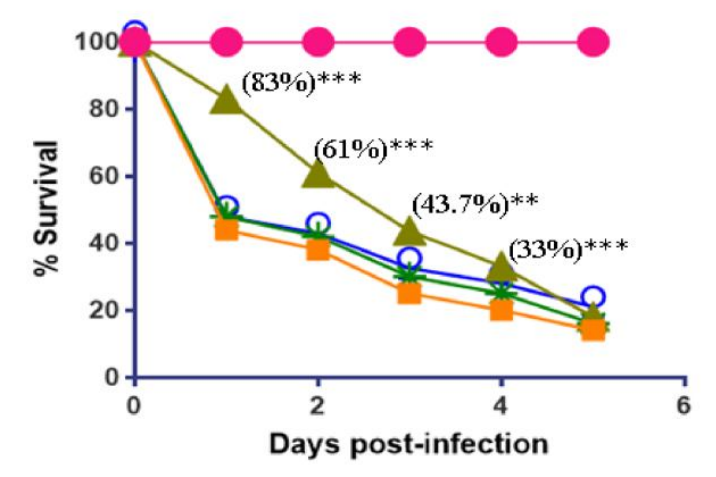

Unchallenged C. elegans

C. elegans challenged with $S$. aureus without microwave treatment

C. elegans challenged with $S$. aureus culture originated from MW (2 min)-exposed inoculum

* C. elegans challenged with $S$. aureus culture originated from MW (4 min)-exposed inoculum

우 C. elegans challenged with S. aureus culture originated from MW (6 min)-exposed inoculum

Figure 11: $S$. aureus culture resulting from MW (2 min)-exposed inoculum expressed reduced virulence towards $C$. elegans

Values reported are means of 4 independent experiments; **p $<0.01, * * * \mathrm{p}<0.001$ 


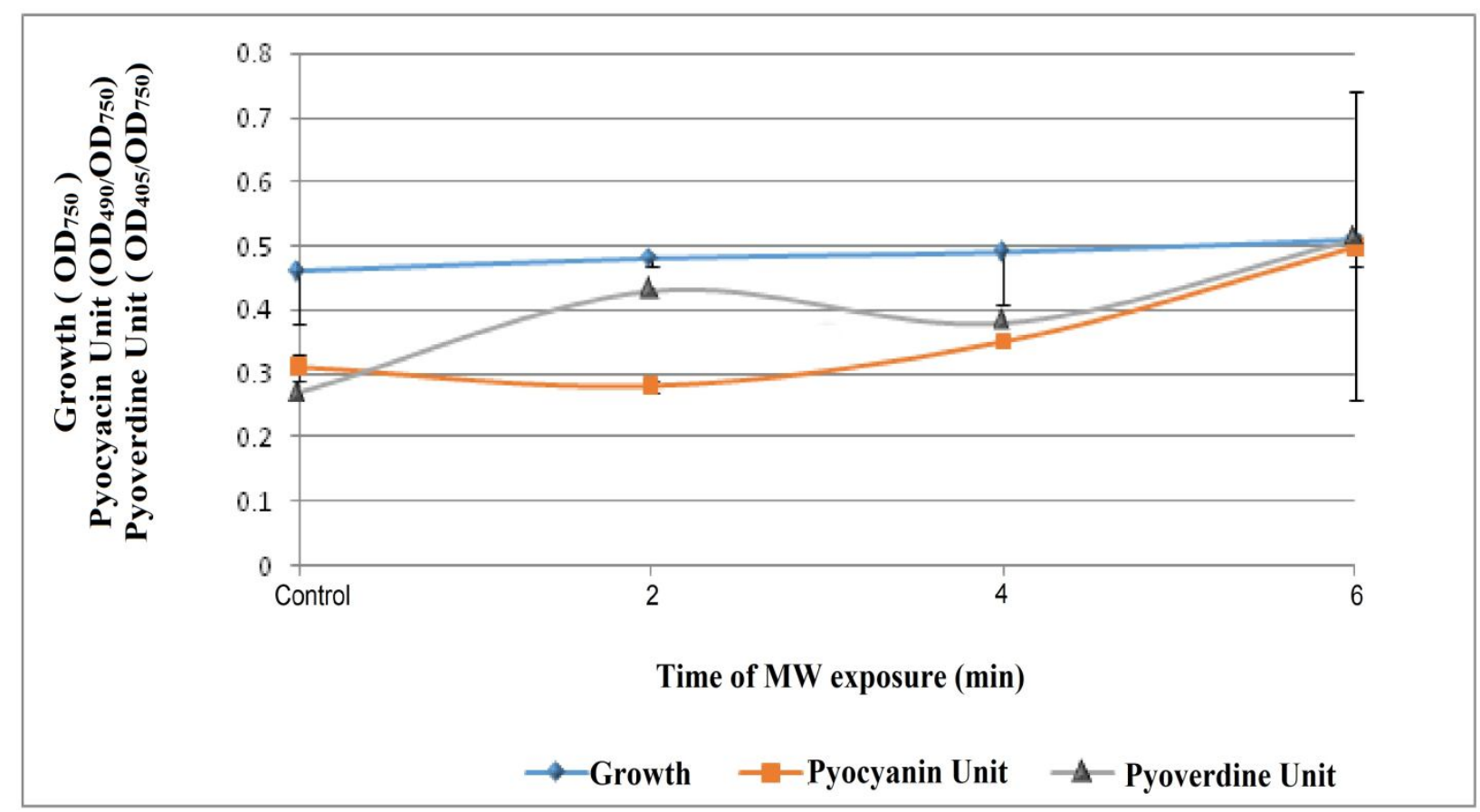

Figure 12. MW treatment did not affect $P$. aeruginosa growth and pigment production

Bacterial growth was measured as $\mathrm{OD}_{750}$; OD of pyoverdine was measured at $405 \mathrm{~nm}$, pyocyanin was measured at $520 \mathrm{~nm}$. Pyoverdine Unit was calculated as the ratio $\mathrm{OD}_{405} / \mathrm{OD}_{750}$ (an indication of pyoverdine production per unit of growth); Pyocyanin Unit was calculated as the ratio $\mathrm{OD}_{490} / \mathrm{OD}_{750}$ (an indication of pyocyanin production per unit of growth); Bacterial culture receiving no MW exposure served as acontrol. Extraction and quantification of the pigments pyoverdine and pyocyanin was carried out as described in El-Fouly et al. (2015) and Unni et al. (2014) respectively. 


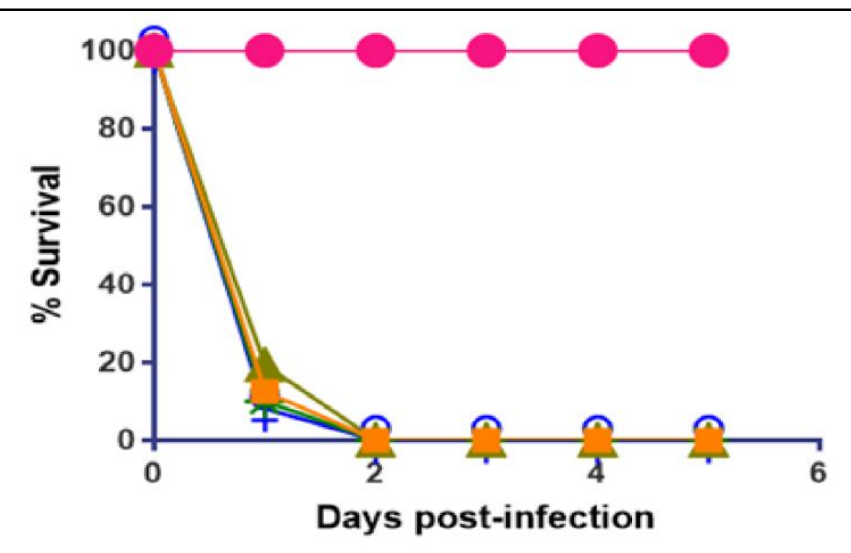

Unchallenged C. elegans

C. elegans challenged with $P$. aeruginosa without microwave treatment

C. elegans challenged with $P$. aeruginosa culture originated from MW $(2 \mathrm{~min})$-exposed inoculum

C. elegans challenged with $P$. aeruginosa culture originated from MW (4 min)-exposed inoculum

우 C. elegans challenged with $P$. aeruginosa culture originated from MW (6 min)-exposed inoculum

Figure 13. Microwave treatment was not found to alter virulence of $P$. aeruginosa towards C. elegans

Values reported are means of 4 independent experiments. 